\title{
A new species of the genus Phradonoma Jacquelin du Val, 1859 from Ethiopia (Coleoptera: Dermestidae: Megatominae)
}

\author{
JIŘÍ HÁvA \\ ${ }^{1}$ Daugavpils University, Institute of Life Sciences and Technology, \\ Coleopterological Research Center, Vienības Str. 13, Daugavpils, LV - 5401, Latvia \\ ${ }^{2}$ Private Entomological Laboratory and Collection, \\ Rýznerova 37, CZ - 25262 Únětice u Prahy, Praha-západ, Czech Republic \\ e-mail: jh.dermestidae@volny.cz
}

HÁva, J.: A new species of the genus Phradonoma Jacquelin du Val, 1859 from Ethoipia (Coleoptera: Dermestidae: Megatominae).

Abstract: Phradonoma hulai sp. nov. from Ethiopia is described, illustrated and compared with the species $P$. zavattari Háva, 2015 (Ethiopia) belonging to the "Phradonoma nobile species group". The new species is characteristic by the structure of antennae, male genitalia and colour of the elytral setation.

Keywords: taxonomy, new species, new records, Coleoptera, Dermestidae, Phradonoma, Ethiopia.

\section{Introduction}

The genus Phradonoma currently contains 46 species distributed in the Palaearctic and Afrotropical Regions. Only one species was introduced into the United States and Australia (Háva 2015, 2019).

During the determination of some Dermestidae material deposited in the National Museum, Prague, the author found a new Phradonoma Jacquelin du Val, 1859 species from Ethiopia described below.

\section{Material and methods}

The size of the beetles or of their body parts can be useful in species recognition and thus, the following measurements were made:

TL: total length - linear distance from anterior margin of pronotum to apex of elytra.

EW: elytral width - maximum linear transverse distance. 
The type specimens are deposited in the following collections:

NMPC - National Museum, Prague, Czech Republic;

JHAC - Jiří Háva, Private Entomological Laboratory \& Collection, Únětice u Prahy, Prague-West, Czech Republic.

Specimens of the described species are provided with red, printed labels with the text as follows: „HOLOTYPE (or PARATYPE, respectively) Phradonoma hulai sp. nov. Jiří Háva det. 2019".

The nomenclature and zoogeography follow Háva (2015).

\section{Description}

Genus Phradonoma Jacquelin du Val, 1859

"Phradonoma nobile species group"

Phradonoma hulai sp. nov. (Figs. 1-3)

Type material. Holotype (ð): ETHIOPIA, Ginir prov., forest in valley to Sof Omar cave, 1249 m, 16.vi.2011, V. Hula, J. Niedobová \& M. Moradmand leg., (NMPC). Paratypes (11 spec.): same data as holotype, (8 NMPC, 3 JHAC).

Description of holotype. Male. Body black and brown, oval. Body measurements (mm): TL 2.8 EW 1.9.

Head coarsely punctuate, with short more or less decumbent white-yellow setae, maxillary palpi darkish brown, eyes large with microsetae, antennae with 11 antennomeres with three antennomered club. Antennomere I is dark brown, antennomeres II-VIII are brown, IX-XI brownish-black (Fig. 4). Forehead with ocellus.

Pronotum entirely dark black, shiny, sparsely and not very coarsely punctate, with intermixed white and yellow erect setae. Lateral margins slightly visible from above.

Scutellum small, black, triangular, without setation or punctures.

Elytra black with brown apical part, sparsely and coarsely punctate, sparsely covered by slightly erect brown and white setation. Each elytron with small isolated white spots arranged in narrow fasciae. The underside of the specimen coarsely and (especially the visible ventrite) more densely punctate than elytra and pronotum, covered with straight and decumbent white-yellowish setae.

Tibiae and tarsi brown, femora anteriorly darkened and sparsely covered with fine brown hairs, anterior tibiae with dark brown thorns. Male genitalia as in Fig. 3.

Female. Externally very similar to male, but the antenna is a little bit shorter with a slightly smaller club (Fig. 2).

Variability. Body very dark brown to black with brown apical part; measurements (mm): TL 1.9-3.3. The apical brown area varies in size.

Differential diagnosis. The new species belongs to the "Phradonoma nobile species group" as defined by Háva et al. (2013). The new species very similar to P. zavattari Háva, 2015 (Ethiopia) but differs from it and other known Afrotropical species belonging to the species group by the structure of antennae and male genitalia.

Etymology. Patronymic, dedicated to the collector of the new species and my friend Vladimír Hula (Brno, Czech Republic). 

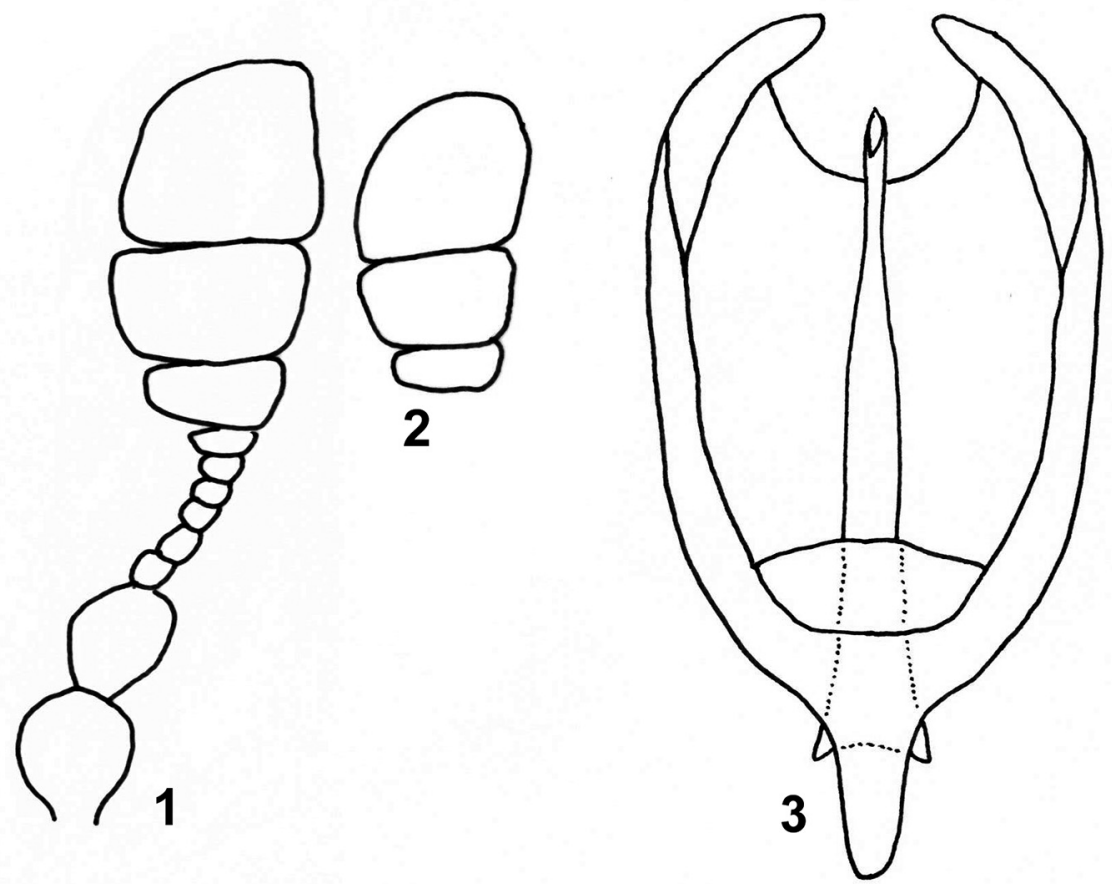

Figs. 1-3. Phradonoma hulai sp. nov.: 1- male antenna; 2- female antennal club; 3- male genitalia

Phradnonoma zavattari Háva, 2015

(Figs. 4-6)

Material examined: Ethiopia, Shoa, Debre Zeyt, v. 1989, K. Werner legit., 1 đૈ, J. Háva det., (JHAC).

Distribution. The species known from Ethiopia according to the type material, new locality data from Ethiopia.

Phradonoma eximium (Arrow, 1915)

Phradonoma eximium var. inhumeralis Kalík, unpublished name.

Remarks. In Natural History Museum, London, United Kingdom specimens of Phradonoma eximium var. inhumeralis Kalík (S. Africa, Zululand, Lr. Umhlatuzi R. G., 6.vi.1926, R.E. Turner, Brit. Mus. 1926-27) are deposited. The variety is undescribed and differs from the typical specimens by the missing humeral orange fascia. In the author's collection, there is a specimen the same colour from Tanzania E., Utete, Rufuji riv., 23.12.2006, Snížek lgt. All these specimens are identical with typical specimens in other characters. 

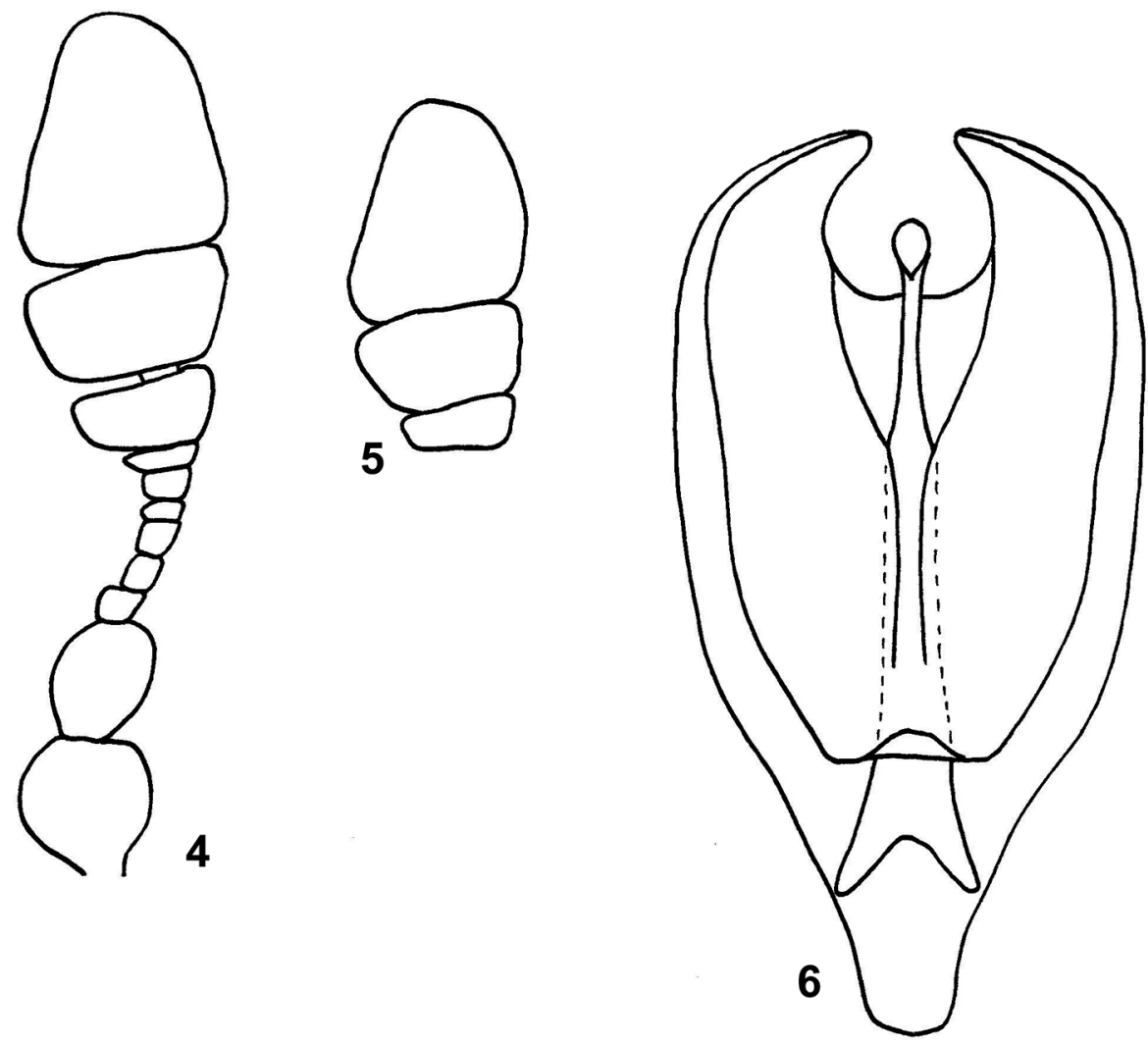

Figs. 4-6. Phradonoma zavattari Háva, 2015: 4- male antenna; 5- female antennal club; 6- male genitalia

\section{Acknowledgements}

I am obliged to Jiří Hájek (NMPC) for the loan of interesting material from Ethiopia and to Miloslav Rakovič (Czech Republic) for linguistic correction.

\section{References}

HávA, J. 2015: World Catalogue of Insects. Volume 13. Dermestidae (Coleoptera). Leiden/Boston: Brill, xxvi $+419 \mathrm{pp}$.

Háva, J. 2019: Contribution to the knowledge of genus Phradonoma Jacquelin du Val, 1859 from the Afrotropical Region (Coleoptera: Dermestidae: Megatominae). - Natura Somogyiensis 33: 5-10.

Háva, J., Lackner, T. \& Mazancová, J. 2013: Description of Phradonoma blabolili sp. n. from Angola (Coleoptera, Dermestidae, Megatominae), with notes on the dermestid beetles from Angola. - ZooKeys 293: 65-76. 